\title{
Immune Checkpoint Inhibitors in Oral Cavity Squamous Cell Carcinoma and Oral Potentially Malignant Disorders: A Systematic Review
}

\author{
Omar Kujan ${ }^{1, *(D)}$, Bede van Schaijik ${ }^{1}$ (D) and Camile S. Farah 2,3,4 (D) \\ 1 UWA Dental School, The University of Western Australia, Nedlands, WA 6009, Australia; \\ 22582886@student.uwa.edu.au \\ 2 Australian Centre for Oral Oncology Research \& Education, Nedlands, WA 6009, Australia; \\ camile@oralmedpath.com.au \\ 3 Oral, Maxillofacial and Dental Surgery, Fiona Stanley Hospital, Murdoch WA 6150, Australia \\ 4 Genomics for Life, Herston QLD 4006, Australia \\ * Correspondence: omar.kujan@uwa.edu.au; Tel.: +61-8-6457-7649
}

Received: 2 June 2020; Accepted: 16 July 2020; Published: 17 July 2020

\begin{abstract}
Cancers of the oral cavity cause significant cancer-related death worldwide. While survival rates have improved in recent years, new methods of treatment are being investigated to limit disease progression and to improve outcomes, particularly in oral cavity squamous cell carcinoma (OSCC) and oral potentially malignant disorders (OPMD). The emerging treatment modality of immunotherapy targets immune checkpoint molecules including PD-1 and its ligand PD-L1, CTLA-4, LAG-3, and TIM-3 to enhance the host immune response against tumours, and to limit the growth and progression of cancer cells. In this systematic review, we searched five databases for keywords pertaining to oral cancers and OPMDs, along with immune checkpoint inhibitors, in order to summarize the current status of their use and efficacy in these diseases. A total of 644 different articles were identified between 2004 and 2019, with 76 deemed suitable for inclusion in the study, providing a total of 8826 samples. Combined results show expression of PD-1 and PD-L1 in the majority of OPMD and OSCC samples, with expression correlating with increased progression and decreased survival rates. Immunotherapy agents pembrolizumab and nivolumab target PD-1 and have been shown to prolong survival rates and improve disease outcomes, especially in combination with chemotherapy or radiotherapy. Despite the equivocal nature of current evidence, there is support for the prognostic and predictive value of immune checkpoint molecules, especially PD-L1, and many studies provide support for the effective use of immune checkpoint inhibitors in the management of OSCC. Limited data is available for OPMD, therefore this should be the focus of future research.
\end{abstract}

Keywords: immune checkpoint inhibitors; PD-1; PD-L1; oral squamous cell carcinoma; oral potentially malignant disorders

\section{Introduction}

Cancer survival rates have improved significantly over the last few years [1]. In the treatment of head and neck malignancies, including oral cavity squamous cell carcinoma (OSCC), immune checkpoint inhibitors constitute a significant breakthrough influencing treatment outcomes and improving overall survival [1]. The use of monoclonal antibodies that block inhibitory immune checkpoint molecules, enhances the immune response to tumours, and consequently controls the growth and spread of neoplastic cells [2,3]. Immune checkpoint blockade removes inhibitory signals of T-cell activation, which enable tumour-reactive $\mathrm{T}$ cells to overcome regulatory mechanisms and mount an effective anti-tumour response [4]. The goal of cancer immunotherapy is to boost or restore 
the ability of the immune system to detect and destroy cancer cells. This is achieved by overcoming the mechanisms by which tumours evade and suppress the immune response, in essence, shifting the equilibrium back in favor of immune protection [5]. Regulatory T-cells play an important role in the tumour microenvironment (TME). They can mediate tolerance, suppress effector T-cells, and inhibit immune-mediated destruction. Amarnath et al. demonstrated that regulatory T cells (Tregs) cause dendritic cells to increase PD-L1 expression by affecting the PD-1-PD-L1 pathway [6]. PD-L1 expression by tumour cells can lead to evasion of the immune response by inhibiting T-cell responses through conversion of TH1 CD4 T-cells to Tregs [6]. This results in increased suppressive activity. PD-1/PD-L1 expression varies among different types of cancers and premalignant disorders. Immune checkpoint molecules include: PD-1, PD-L1, CTLA-4, TIM-3 and LAG-3. Targeted therapy with PD-1 or PD-L1 monoclonal antibodies shows durable tumour regression in patients with non-small cell lung cancer (NSCLC) who were non-responsive to chemotherapy or radiotherapy [7]. Phase I trials with anti-PD-1 or anti-PD-L1 have shown response rates of $18-28 \%$ and $10-17 \%$, respectively, in patients with melanoma, NSCLC, and renal carcinoma [8]. PD-1 inhibitors pembrolizumab (Keytruda) and nivolumab (Opdivo) are used in the treatment of melanoma of the skin, NSCLC, kidney cancer, head and neck squamous cell carcinoma (HNSCC), and Hodgkins lymphoma, while PD-L1 inhibitors such as atezolizumab (Tecentriq) are used in the treatment of bladder cancer [9]. Clinical trials have demonstrated the utility of PD-1 and PD-L1 inhibitors in a wide variety of applications with relatively less toxic side effects compared to chemotherapy and radiotherapy [9]. Other immune checkpoint biomarkers that have shown promising results include CTLA-4, LAG-3, and TIM-3. When comparing PD-1/PD-L1 expression in HNSCC versus other epithelial cancers, one unique feature is its association with human papillomavirus (HPV), which has been shown to be the driver of carcinogenesis in $40-80 \%$ of oropharyngeal carcinomas, but not in malignancies arising from the oral cavity or other head and neck sites [10]. Recently the role of PD-1 and PD-L1 has been explored in premalignant lesions known collectively as oral potential malignant disorders (OPMD). In a group of patients with actinic cheilitis, the over-expression of PD-1/PD-L1 was higher than that of healthy volunteers but lower than that observed in OSCC [11]. This was investigated in order to identify the possibility of targeting immune checkpoint molecules prior to progression of OPMDs to OSCC. This systematic review aimed to unravel the expression of immune checkpoint biomarkers in the oral cavity subset of HNSCC, and to compare that in precursor lesions; OPMDs. A secondary aim was to identify biomarkers with prognostic or predictive value and to explore the role of therapeutic agents and their efficacy in the management of oral cavity SCC.

\section{Materials and Methods}

This systematic review was performed and reported according to the Preferred Reporting Items for Systematic Review and Meta-analysis (PRISMA) [12]. The article selection flow chart is presented in Figure 1. 


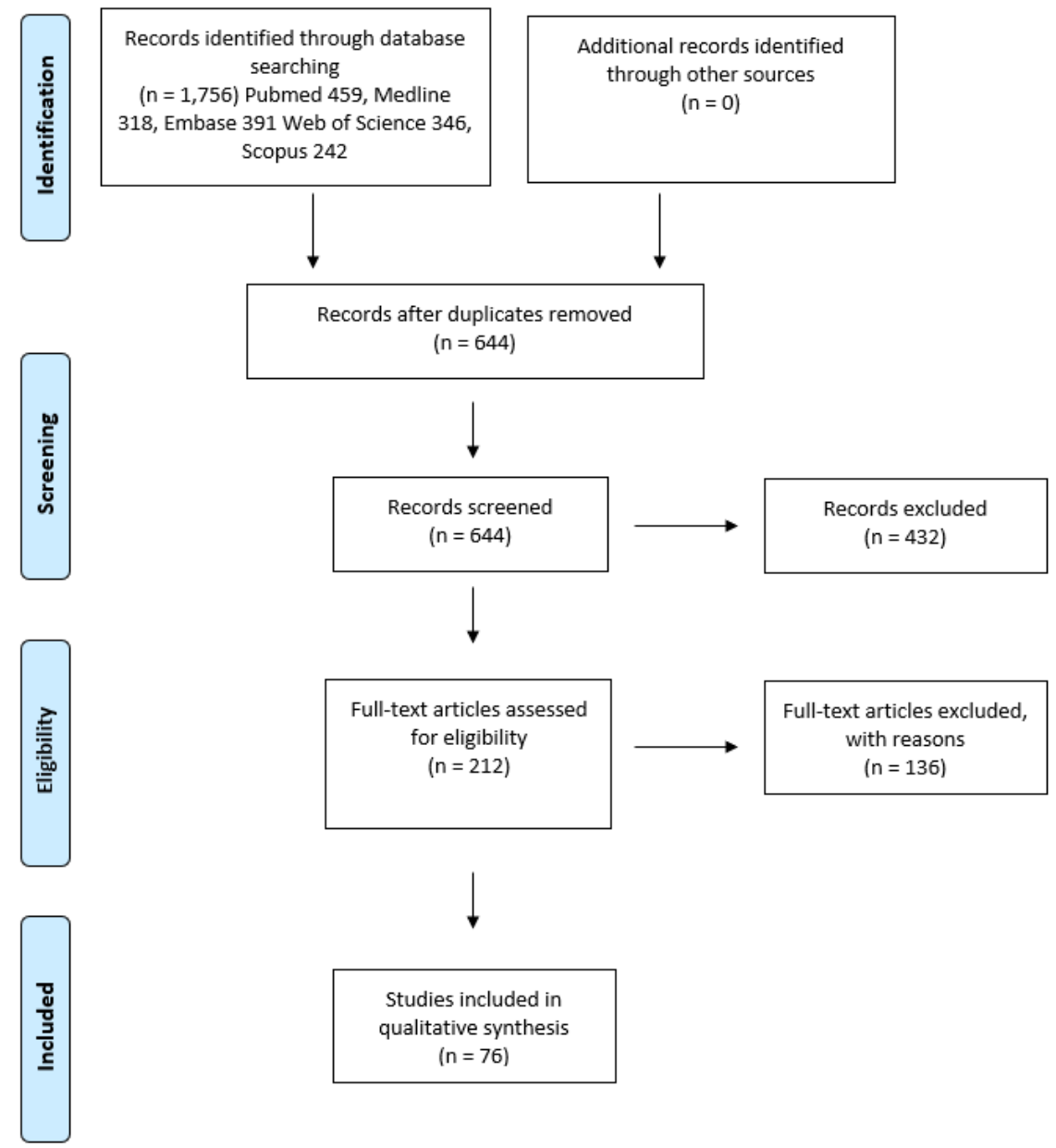

Figure 1. Article selection flow chart for the systematic review using Preferred Reporting Items for Systematic Review and Meta-analysis (PRISMA) guidelines.

\subsection{PICO Statement}

For this systematic review, the population of interest was patients with OSCC and OPMD of the oral cavity, the intervention was the use of immune checkpoint inhibitors, and the controls were normal healthy oral tissues. The outcome was to determine the effect of immune checkpoint inhibitors on the survival of patients with OSCC or OPMD.

\subsection{Data Sources and Search Strategy}

Electronic databases were searched by two authors (B.V.S. and O.K.). The databases searched were as follows: MEDLINE, EMBASE, PubMed, Web of Science and Scopus. The search strategies were developed using the specific (Medical Subject Headings) MeSH terms demonstrated in Table 1. References were checked from bibliographies in relevant articles and included in the systematic review if they were not identified initially. The search strategy included all studies published up to the end of December 2019. 
Table 1. Medical Subject Headings (MeSH) Terms for the Search Strategy.

\begin{tabular}{cc}
\hline No. & Search Strategy \\
\hline 1 & $\begin{array}{r}\text { Oral or gingiva or buccal or tongue or oropharyngeal or cheek or lip or lingual or floor } \\
\text { of the mouth or tonsils or retromolar or palate or mandible or maxilla }\end{array}$ \\
\hline 2 & $\begin{array}{r}\text { Squamous cell carcinoma or epithelial dysplasia or oral potentially malignant disorders } \\
\text { or oral potentially malignant lesions or oral precancer or oral cancer or leukoplakia or } \\
\text { lichen planus or erythroplakia or OSCC }\end{array}$ \\
\hline 3 & PD-1 or PDL-1 or PD-1 or PDL1 or CD274 or CD279 or CTLA-4 or CTLA4 or LAG-3 or \\
LAG3 or TIM-3 or TIM3 or CD152 or CD223 or immune checkpoint inhibitors
\end{tabular}

\subsection{Study Selection and Data Extraction}

Initial studies identified through database searching were screened according to title and abstract against the inclusion criteria. The inclusion criteria were restricted to English language, immune checkpoint inhibitors as specified in the search statement, and lesions or tumours in the oral cavity. Review articles, case reports, non-English articles, animal studies or studies using cell lines were excluded. All studies considered eligible were included for full-text evaluation. When there was disagreement between the reviewers on whether to include or exclude a study, it was resolved through discussion. Then data were extracted from each included study using a standardised data collection form including lead author, publication year, study inclusion and exclusion criteria (when available), type of investigated specimens, sample size, subject breakdown (when available), subsites (when available), method of detection, and follow-up periods (when available), in addition to data on drug efficacy.

The main outcomes of this systematic review were to:

(1) Report on the expression of immune checkpoint biomarkers in OSCC and compare that to OPMD; (2) Establish whether the studied biomarkers had prognostic or predictive value; (3) Explore the role of recent therapeutic agents and their efficacy in the management of OSCC.

\subsection{Quality Assessment}

Evaluation of the studies included in the systematic review were assessed using the Quality Assessment of Diagnostic Accuracy Studies 2 (QUADAS-2) revised tool for the quality assessment of diagnostic accuracy studies [13], and Quality In Prognosis Studies (QUIPS) for prognostic and predictive studies [14].

\section{Results}

The initial search generated a total of 1756 articles from all databases used (PubMed 459, MEDLINE 318, EMBASE 391, Web of Science 346 and Scopus 242). After removing duplicates, a total of 644 articles were identified. These articles were assessed against the inclusion and exclusion criteria. In total, 433 articles were excluded after reading the abstract. A total of 212 articles were eligible for full-text assessment. An additional 136 articles were excluded after reading the full text as they did not meet the inclusion/exclusion criteria. A total of 76 studies met the criteria used in this systematic review (Table S1). The year of publication ranged from 2004 to 2019. A total of 8826 samples were investigated; 8322 OSCC and 504 OPMD samples, respectively. The average age of all OSCC subjects was 61.2 years (range 15-96) and the male to female ratio was 2.8. The average age of all OPMD subjects was 50.17 years (range 8-105) and the male to female ratio was 1.388. A summary of the expression patterns, as well as the main findings from the included articles, are presented in Table S2.

The most common methodology for assessing expression of immune checkpoint biomarkers was immunohistochemistry (IHC) in 38 studies [10,15-51], followed by flow cytometry (FC) and polymerase chain reaction (PCR) with 10 [52-61] and 8 [62-69] studies, respectively. A combination of both IHC and PCR were used in seven studies [70-76], both IHC and FC in four [11,77-79], and one 
study used a combination of IHC, PCR and FC [80]. In situ hybridization [81], immunoblotting [82], cell sorting [83] and genotyping [84] were used in a single study each, and four studies had alternative methodologies [85-88] such as computed tomography [85], tumor growth kinetics analysis [86], radiographic analysis [87], and observed treatment response [88].

PD-L1 was the most studied biomarker, analyzed in 53 studies $[10,11,15-32,34-37,39-46,48,50,54$, $59-61,64,65,67,68,70-72,74-78,80,81,86]$, followed by PD-1 in 25 studies $[11,15,24,26,35,38,43,47,49,51$, $53,56,58,59,61,66,73,74,77-81,84,86]$ and CTLA-4 in 16 studies $[33,45,46,52,54-58,62,63,69,74,77,80,82]$. Other biomarkers analyzed were TIM-3 and LAG-3 in nine $[45,49,53,56,58,59,77,79,83]$ and four $[45,49$, 56,78] studies, respectively.

Oral cavity, with 1249 samples, was the most reported site for OSCC. Other anatomical subsites specifically reported included oral tongue, floor of mouth, buccal mucosa, gingiva, alveolus, hard palate, lip, and retromolar trigone with $713,275,112,111,55,44,44$, and 38 samples, respectively. A range of OPMD types were reported, the most common being OLP with 233 samples, followed by oral leukoplakia with 129 , non-specified oral precancerous lesions with 120, and actinic cheilitis with 22 samples.

Quality assessment of included diagnostic accuracy studies was performed using the QUADAS-2 tool, which assessed bias domains of patient selection, index tests, reference standards, and overall flow (Table 2). Quality assessment of included predictive and prognostic studies was performed using the QUIPS tool, which assessed the risk of bias for participation, attrition, prognostic factor and outcome measurements, confounding, and statistical analysis (Table 3). Overall, the quality of the included papers was low, with poor quality of reference standards and a higher than expected level of bias. While this poses practical issues in terms of obtaining healthy samples, future studies should focus on comparing tumour data to appropriate controls, such as patient matched non-diseased oral mucosa, in order to more accurately gauge the effect of immune checkpoint inhibitors on tumour progression and patient survival. 
Table 2. Quality Assessment of Diagnostic Accuracy Studies Using the Diagnostic Accuracy Studies 2 QUADAS-2 Revised Tool.

\begin{tabular}{|c|c|c|c|c|c|c|c|}
\hline \multirow{2}{*}{ Author/Year } & \multicolumn{2}{|c|}{ Domain 1: Patient Selection } & \multicolumn{2}{|c|}{ Domain 2: Index test(s) } & \multicolumn{2}{|c|}{ Domain 3: Reference Standard } & \multirow{2}{*}{$\begin{array}{c}\begin{array}{c}\text { Domain 4: } \\
\text { Flow and } \\
\text { timing }\end{array} \\
\text { Risk of Bias }\end{array}$} \\
\hline & $\begin{array}{l}\text { (A) Risk of } \\
\text { Bias }\end{array}$ & $\begin{array}{l}\text { (B) Concerns } \\
\text { regarding } \\
\text { applicability }\end{array}$ & $\begin{array}{l}\text { (A) Risk of } \\
\text { Bias }\end{array}$ & $\begin{array}{l}\text { (B) Concerns } \\
\text { regarding } \\
\text { applicability }\end{array}$ & $\begin{array}{l}\text { (A) Risk of } \\
\text { Bias }\end{array}$ & $\begin{array}{l}\text { (B) Concerns } \\
\text { regarding } \\
\text { applicability }\end{array}$ & \\
\hline Aggarwal et al. 2017 [82] & high & high & low & low & unclear & unclear & low \\
\hline Bharti et al. 2013 [62] & low & low & low & low & low & low & low \\
\hline Chen et al. 2018 [20] & high & low & high & unclear & low & low & low \\
\hline Chen et al. 2019 [22] & low & low & low & low & low & low & low \\
\hline Cho et al. 2011 [23] & low & low & low & low & low & low & low \\
\hline Dong et al. 2017 [83] & low & unclear & unclear & unclear & unclear & unclear & low \\
\hline Du et al. 2011 [71] & low & low & low & low & low & low & low \\
\hline Fayette et al. 2017 [85] & low & high & low & low & low & low & high \\
\hline Ferris et al. 2017 [25] & low & low & low & low & low & low & high \\
\hline Gasparoto et al. 2010 [52] & low & unclear & low & low & low & low & low \\
\hline Ghapanchi et al. 2019 [84] & Low & Low & Low & Low & Low & Low & Low \\
\hline Jie et al. 2013 [56] & low & low & low & low & low & low & low \\
\hline Kämmerer et al. 2010 [63] & unclear & unclear & low & low & low & low & unclear \\
\hline Katou et al. 2007 [73] & low & low & low & unclear & low & low & high \\
\hline Larkins et al. 2017 [88] & high & high & unclear & unclear & low & low & high \\
\hline Lechner et al. 2017 [80] & low & low & low & low & low & low & low \\
\hline Leduc et al. 2017 [28] & low & low & unclear & unclear & low & low & unclear \\
\hline Linedale et al. 2017 [77] & low & low & low & low & low & low & low \\
\hline Malm et al. 2015 [78] & high & high & low & low & unclear & unclear & unclear \\
\hline
\end{tabular}


Table 2. Cont

\begin{tabular}{|c|c|c|c|c|c|c|c|}
\hline \multirow{2}{*}{ Author/Year } & \multicolumn{2}{|c|}{ Domain 1: Patient Selection } & \multicolumn{2}{|c|}{ Domain 2: Index test(s) } & \multicolumn{2}{|c|}{ Domain 3: Reference Standard } & \multirow{2}{*}{$\begin{array}{c}\begin{array}{c}\text { Domain 4: } \\
\text { Flow and } \\
\text { timing }\end{array} \\
\text { Risk of Bias }\end{array}$} \\
\hline & $\begin{array}{l}\text { (A) Risk of } \\
\text { Bias }\end{array}$ & $\begin{array}{l}\text { (B) Concerns } \\
\text { regarding } \\
\text { applicability }\end{array}$ & $\begin{array}{l}\text { (A) Risk of } \\
\text { Bias }\end{array}$ & $\begin{array}{l}\text { (B) Concerns } \\
\text { regarding } \\
\text { applicability }\end{array}$ & $\begin{array}{l}\text { (A) Risk of } \\
\text { Bias }\end{array}$ & $\begin{array}{l}\text { (B) Concerns } \\
\text { regarding } \\
\text { applicability }\end{array}$ & \\
\hline Mattox et al. 2017 [31] & low & low & low & unclear & low & low & low \\
\hline Oliveira-Costa et al. 2015 [75] & low & low & low & low & low & low & low \\
\hline Poropatich et al. 2017 [58] & low & low & low & low & low & low & low \\
\hline Quan et al. 2016 [79] & low & unclear & low & low & low & low & low \\
\hline Rasmussen et al. 2019 [37] & Low & Low & Low & Low & unclear & unclear & low \\
\hline Saâda-Bouzid et al. 2017 [86] & low & low & low & low & high & unclear & low \\
\hline Satgunaseelan et al. 2017 [40] & low & low & low & low & low & low & low \\
\hline Scognamiglio et al. 2017 [10] & low & unclear & low & low & low & low & low \\
\hline Strauss et al. 2017 [55] & unclear & unclear & low & low & unclear & unclear & high \\
\hline Strati et al. 2017 [67] & low & low & low & low & low & low & low \\
\hline Takahashi et al. 2019 [42] & low & low & low & low & unclear & unclear & unclear \\
\hline Takakura et al. 2017 [43] & low & unclear & low & low & low & low & low \\
\hline Wirsing et al. 2018 [76] & low & low & low & low & low & low & low \\
\hline Wu et al. 2017 [46] & low & low & low & low & low & low & low \\
\hline Xu et al. 2019 [47] & low & low & unclear & unclear & unclear & unclear & high \\
\hline Yang et al. 2019 [49] & low & low & low & low & low & low & low \\
\hline $\begin{array}{l}\text { Youngnak-Piboonratanakit et } \\
\text { al. } 2004 \text { [51] }\end{array}$ & low & low & high & low & low & low & low \\
\hline Zhou et al. 2012 [61] & unclear & low & low & low & unclear & unclear & high \\
\hline
\end{tabular}


Table 3. Quality Assessment of Studies of Prognostic Factors Using the Quality In Prognosis Studies QUIPS Tool.

\begin{tabular}{|c|c|c|c|c|c|c|}
\hline \multirow[b]{2}{*}{ Author/Year } & \multicolumn{6}{|c|}{ Risk of Bias for Each Domain } \\
\hline & Study Participation & Study Attrition & $\begin{array}{c}\text { Prognostic Factor } \\
\text { Measurement }\end{array}$ & $\begin{array}{c}\text { Outcome } \\
\text { Measurement }\end{array}$ & $\begin{array}{c}\text { Study } \\
\text { Confounding }\end{array}$ & $\begin{array}{l}\text { Statistical Analysis } \\
\text { and Reporting }\end{array}$ \\
\hline Ahn et al. 2017 [70] & Moderate & Low & Low & Low & Moderate & Low \\
\hline Balermpas et al. 2017 [15] & Low & Low & Low & Low & Moderate & Low \\
\hline Bauml et al. 2017 [16] & Moderate & Low & Low & Low & Low & Low \\
\hline Cai et al. 2019 [19] & Low & Low & Low & Moderate & Moderate & Low \\
\hline Chen et al. 2015 [21] & Moderate & Low & Low & Moderate & Moderate & Moderate \\
\hline Falco et al. 2019 [87] & Low & Low & High & High & Moderate & High \\
\hline Fiedler et al. 2017 [26] & Moderate & High & Low & Low & Low & High \\
\hline Foy et al. 2017 [27] & Low & Low & Low & Low & Low & Low \\
\hline Goltz et al. 2017 [66] & Moderate & Low & Moderate & Moderate & Moderate & Low \\
\hline Groeger et al. 2016 [17] & High & Low & Low & Low & Low & Low \\
\hline Hanna et al. 2017 [72] & Low & Low & Low & Low & Low & Low \\
\hline Hanna et al. 2017 [53] & Low & High & Low & Low & Moderate & Low \\
\hline Lecerf et al. 2019 [74] & Low & Low & Moderate & Low & Low & Low \\
\hline Lin et al. 2015 [29] & Low & Low & Low & Low & Low & Low \\
\hline Malaspina et al. 2011 [11] & Low & Low & Low & Moderate & Moderate & Low \\
\hline Maruse et al. 2018 [30] & Moderate & Low & Low & Moderate & Moderate & Low \\
\hline Moratin et al. 2019 [32] & Moderate & Low & Low & Low & Moderate & Low \\
\hline Moreira et al. 2010 [33] & Low & Moderate & Low & Moderate & Low & Low \\
\hline Muller et al. 2017 [34] & Low & Low & Low & Moderate & Low & Low \\
\hline Naruse et al. 2019 [35] & Moderate & Low & Low & Moderate & High & Moderate \\
\hline Ngamphaiboon et al. 2019 [36] & Low & Low & Moderate & Moderate & Moderate & Moderate \\
\hline Okada et al. 2018 [18] & High & Moderate & Low & Low & Low & Low \\
\hline Ryu et al. 2017 [38] & Low & Moderate & Moderate & Moderate & High & Moderate \\
\hline
\end{tabular}


Table 3. Cont.

\begin{tabular}{|c|c|c|c|c|c|c|}
\hline \multirow[b]{2}{*}{ Author/Year } & \multicolumn{6}{|c|}{ Risk of Bias for Each Domain } \\
\hline & Study Participation & Study Attrition & $\begin{array}{c}\text { Prognostic Factor } \\
\text { Measurement }\end{array}$ & $\begin{array}{c}\text { Outcome } \\
\text { Measurement }\end{array}$ & $\begin{array}{c}\text { Study } \\
\text { Confounding }\end{array}$ & $\begin{array}{c}\text { Statistical Analysis } \\
\text { and Reporting }\end{array}$ \\
\hline Sablin et al. 2016 [39] & Moderate & Low & Moderate & High & High & High \\
\hline Seiwert et al. 2016 [41] & Low & Moderate & Moderate & High & Moderate & Low \\
\hline Shayan et al. 2017 [54] & High & Low & Low & Low & Low & Low \\
\hline Sridharan et al. 2016 [59] & High & Low & Moderate & Low & Moderate & Low \\
\hline Straub et al. 2016 [81] & Low & Low & Low & Low & Low & Low \\
\hline Troeltzsch et al. 2017 [44] & Low & Low & Low & Low & Moderate & Low \\
\hline Wang et al. 2019 [45] & Moderate & Low & Moderate & Moderate & High & Low \\
\hline Weber er al. 2018 [68] & Low & Moderate & Low & Low & Moderate & Low \\
\hline Wong et al. 2006 [69] & Low & High & Low & Low & Low & Low \\
\hline Wu et al. 2019 [60] & High & Moderate & Low & Low & High & High \\
\hline Yagyuu et al. 2017 [48] & Low & Low & Low & Low & Low & Low \\
\hline Yoo et al. 2019 [50] & Moderate & Moderate & Low & Moderate & Moderate & Low \\
\hline
\end{tabular}




\section{Discussion}

Recently, the role of immune checkpoint inhibitors in the TME has been extensively investigated [27, $42,43,47,48,76,79]$. In this systematic review, we have focused on the role of various immune checkpoint biomarkers and their inhibitors in OSCC and OPMDs.

The role of immune checkpoint inhibitors has also been investigated in OPMDs with the aim of identifying specific biomarkers that can predict OSCC transformation. PD-1 and its ligands were found to be expressed on infiltrating lymphocytes in oral lichen planus (OLP) which may have a role in tolerance induction in inflamed oral mucosa [51,71], however this expression was lower than that expressed on CD8+ infiltrating lymphocytes in early stage tongue OSCC [73]. In addition, a higher percentage of CD8+CD154+ and granzyme B+ cells were found in OLP patients [57]. Gene polymorphisms at position PD-1.3 (rs11568821) have been detected, but not associated with susceptibility to OLP [84]. In contrast, although PD-1 gene polymorphisms at positions PD-1.3 (rs11568821), PD-1.5 (rs2227981) and PD-1.9 (rs2227982) were not solely associated with susceptibility to HNSCCs, haplotype combinations emerging from these three loci may render susceptibility to HNSCCs [89]. The frequency of CD4+ and CD8+ T cells expressing PD-1 was higher in actinic cheilitis compared to normal tissues [11]. According to Yagyuu et al. [48] and Zhou et al. [61], dysplastic lesions expressing PD-L1 on epithelial and subepithelial cells can evade the immune host system, and inhibition of the PD-1/PD-L1 pathway can prevent malignant transformation in OPMDs [48,61]. PD-L1 expression in oral leukoplakia was closely associated with disease progression and CD8+ lymphocytes [22]. Bhosale et al. explored chromosomal alterations and gene expression changes associated with transformation of leukoplakia to OSCC and found that amplifications at 1p36.33 and 11q22.1 were strongly associated with poor clinical outcome [65]. The VISTA protein (V domain Ig suppressor of T cell activation) is more highly expressed in dysplastic tissues compared to normal [46].

The TME of OSCC supports adaptive immune responses that can be maintained through specific antigens [79]. Ngamphaiboon et al. reported that $83.9 \%$ of OSCC samples in their cohort $(n=203)$ showed positive expression of PD-L1 [36], while Takahashi et al. reported low expression in $40 \%$ and high expression in $60 \%$ of OSCC samples $(n=77)$ [42]. PD-1/PD-L1 expression in OSCC has also been associated with increased tumour-infiltrating lymphocytes (TILs) $[60,68,70,81]$. A positive correlation between PD-L1 expression and CD8+ and CD4+ TILs was found in tongue SCC, with higher CD4+ PD-1+ TILs compared to CD8+PD-1+ TILs [31]. CD4 expression was associated with poor prognosis in OSCC compared to CD25, which has a more favourable outcome [33], and combined expression of PD-1/PD-L1 significantly decreased the 5-year disease-specific survival rate [35]. High expression of PD-L1 was associated with poor clinical outcome [29,30]. In OSCC, the frequency of CD4+ and CD8+ T cells expressing PD-1 is higher than actinic cheilitis [11]. CTLA-4 pleomorphism was associated with OSCC age of onset and survival [69]. The role of Tregs in modifying the anti-tumour response has been assessed by Gasparoto et al., who found that they play a part in inhibiting T-cell proliferation and secreting immunosuppressive cytokines [52]. This was also demonstrated in a study by Aggarwal et al. [82]. A recent study suggests that young patients with OSCC have a more favourable outcome with PD-1 blockade when compared to older counterparts [72]. Higher incidence of PD-L1 expression has been reported in OSCC in females with an associated inflammatory phenotype [40]. Strong cytoplasmic expression of PD-L1 was found in circulating tumour cells (CTCs) and this plays a role in limiting $\mathrm{T}$ cell activity in inflammatory responses [75]. In a recent study, high endothelial venules were found to be markers for favourable antitumour immune microenvironments in OSCC [76]. Bharti et al. studied the different genotypes associated with CTLA-4 and showed that the AA genotype had a stronger association with an increased risk of developing OSCC compared to the GG phenotype [62].

PD-L1 expression is common in OSCC at both the transcriptional and protein levels $[34,44,47$, 50,81]. PD-L1 expression was noted to be different between primary and metastatic sites [10,32]. In addition, PD-1, PD-L1, OX40, and CTLA-4 are overexpressed in CTCs [80]. An association between PD-L1 and p16 ${ }^{\mathrm{INK} 4 \mathrm{~A}}$ expression in non-oropharyngeal SCC has been demonstrated [20]. 
In addition, PD-L1 expression was positively associated with p16 and Ki-67 [20,38]. HPV-negative OSCC has higher numbers of CD8+ T cells expressing CTLA-4 compared to HPV-positive OSCC, with non-smokers showing a greater benefit of IDO1 and PD-1/PD-L1 blockade compared to smokers [27,45, 58]. Rasmussen et al. reported that the variable intratumoural expression of PD-L1 limits its utility as a biomarker, however identifying the optimal cutoff point for discriminating between responders and non-responders to specific agents would be a useful mechanism for determining treatment efficacy [37].

The predictive and prognostic value of immune checkpoint biomarkers (Table 4) is examined throughout the included articles. Expression of PD-L1 on tumour cells is predictive of improved overall survival and decreased recurrence rates in patients treated with immunotherapy $[48,53,72]$. Fielder et al. showed an association between PD-L1 expression in tumour cells and radio-sensitivity, and favourable survival following radiotherapy [26], while Seiwert et al. showed that PD-L1 expression levels were predictive of the best overall response and progression-free survival, and that SCC tumours with greater PD-L1 expression by IHC show greater antitumour activity [41]. Groeger et al. [17] showed that the 5-year survival rate of patients whose tissues were positive for B7-H1 (PD-L1) expression was 73.33\% (11 of 15), while Hanna et al. [72] showed that membranous PD-L1 expression was associated with a decreased risk of death among female patients, with a highly statistically significant $(p<0.001)$ hazard ratio of 0.58 . Ferris et al. [25], however, showed that treatment with nivolumab (anti-PD-1) demonstrated favourable outcomes regardless of tumour cell PD-L1 expression, while Satgunaseelan et al. [40] presented no correlation with PD-L1 expression and overall survival in patients receiving post-operative adjuvant therapy, indicating that the efficacy of immune checkpoint inhibitors may also be independent of ligand expression. Conversely, Chen et al. showed that positive PD-L1 expression in OSCC with necrosis had worse survival outcomes and poorer disease control, however this is likely due to hypoxia of surrounding tissue overriding the effects of PD-L1 expression [21]. Moreira et al. found no association between CTLA-4 expression and survival rate in OSCC patients [33]. 
Table 4. Predictive and Prognostic Values of Immune Checkpoint Biomarkers in Relevant Included Studies.

\begin{tabular}{|c|c|c|c|c|}
\hline Author/Year & Biomarker & $\begin{array}{l}\text { Tumour } \\
\text { Type }\end{array}$ & Predictive Value & Prognostic Value \\
\hline $\begin{array}{l}\text { Ahn et al. } 2017 \\
\text { [70] }\end{array}$ & PD-L1 & OsCC & N/A & $\begin{array}{l}\text { High PD-L1 expression was a favourable prognostic } \\
\text { factor for overall survival only in the miR-197 high } \\
\text { subgroup }\end{array}$ \\
\hline $\begin{array}{l}\text { Balermpas et al. } \\
\quad 2017[15]\end{array}$ & PD-1, PD-L1 & OsCC & N/A & $\begin{array}{l}\text { PD-L1 in CD8 cells represents a promising prognostic } \\
\text { marker and could be used to guide treatment with } \\
\text { PD-1/PD-L1 inhibitors }\end{array}$ \\
\hline $\begin{array}{l}\text { Bauml et al. } 2017 \\
{[16]}\end{array}$ & PD-L1 & OscC & $\begin{array}{c}17 \% \text { of patients with PD-L1 expression of }>1 \% \text { of } \\
\text { tumour cell } \\
\text { sresponded to treatment with nivolumab }\end{array}$ & $\mathrm{N} / \mathrm{A}$ \\
\hline Cai et al. 2019 [19] & PD-L1 & OscC & $\begin{array}{l}\text { Anti-PD-1 mAb be more efficacious in poorly } \\
\text { differentiated OSCCs with higher PD-L1 expression }\end{array}$ & $\mathrm{N} / \mathrm{A}$ \\
\hline $\begin{array}{l}\text { Chen et al. } 2015 \\
\text { [21] }\end{array}$ & PD-L1 & OsCC & $\begin{array}{l}\text { OSCC patients with positive tumour PD-L1 } \\
\text { expression may be good candidates for anti-PD-L1 } \\
\text { immunotherapy }\end{array}$ & $\begin{array}{l}\text { OSCC patients with necrosis and positive PD-L1 } \\
\text { expression had worse outcomes and disease control }\end{array}$ \\
\hline $\begin{array}{l}\text { Falco et al. } 2019 \\
\text { [87] }\end{array}$ & PD-L1 & OscC & $\begin{array}{l}\text { In patients with high PD-L1 expression, single-agent } \\
\text { pembrolizumab also improves overall survival } \\
\text { compared with cetuximab plus chemotherapy }\end{array}$ & $\mathrm{N} / \mathrm{A}$ \\
\hline $\begin{array}{l}\text { Fiedler et al. } 2017 \\
\text { [26] }\end{array}$ & PD-1, PD-L1 & OscC & $\begin{array}{c}\text { PD-L1 expression indicates radiosensitivity and } \\
\text { favourable survival }\end{array}$ & $\mathrm{N} / \mathrm{A}$ \\
\hline Foy et al. 2017 [27] & PD-L1 & OscC & $\begin{array}{l}\text { Overexpression of PD-L1 correlated with greater } \\
\text { response to pembrolizumab }\end{array}$ & N/A \\
\hline $\begin{array}{l}\text { Goltz et al. } 2017 \\
\text { [66] }\end{array}$ & PD-1 & OscC & $\begin{array}{l}\text { mPDCD1 is a potential predictive biomarker for } \\
\text { immunotherapies targeting the PD-1/PD-L1 axis }\end{array}$ & $\begin{array}{c}\text { mPDCD1 high was associated with shorter overall } \\
\text { survival }\end{array}$ \\
\hline $\begin{array}{l}\text { Groeger et al. } \\
2016[17]\end{array}$ & PD-L1 & OsCC & $\mathrm{N} / \mathrm{A}$ & $\begin{array}{l}\text { Expression of PD-L1 may be a prognostic marker for } \\
\text { OSCC }\end{array}$ \\
\hline $\begin{array}{l}\text { Hanna et al. } 2017 \\
\text { [72] }\end{array}$ & PD-L1 & OsCC & $\mathrm{N} / \mathrm{A}$ & $\begin{array}{l}\text { Greater membranous PD-L1 positivity and } \\
\text { the presence of TILs showed a decreased risk of } \\
\text { recurrence and improved survival, hazard ratio } 0.58\end{array}$ \\
\hline
\end{tabular}


Table 4. Cont

\begin{tabular}{|c|c|c|c|c|}
\hline Author/Year & Biomarker & $\begin{array}{l}\text { Tumour } \\
\text { Type }\end{array}$ & Predictive Value & Prognostic Value \\
\hline $\begin{array}{l}\text { Hanna et al. } 2017 \\
\text { [53] }\end{array}$ & PD-1, Tim3 & OsCC & $\begin{array}{l}\text { OSCC with inflamed immunophenotype benefit from } \\
\text { single agent PD-1 blockade }\end{array}$ & N/A \\
\hline $\begin{array}{l}\text { Lecerf et al. } 2019 \\
\qquad[74]\end{array}$ & $\begin{array}{l}\text { PD-1, PD-L1, } \\
\text { CTLA-4 }\end{array}$ & OsCC & N/A & $\begin{array}{l}\text { PD-1 overexpression was associated with good } \\
\text { prognosis and low mRNA levels of PD-1 correlated } \\
\text { with poor prognosis and high risk of recurrence }\end{array}$ \\
\hline Lin et al. 2015 [29] & PD-L1 & OSCC & N/A & $\begin{array}{l}\text { High PD-L1-expression was significantly associated } \\
\text { with distant metastasis and poor prognosis in male } \\
\text { patients and smoking patients }\end{array}$ \\
\hline $\begin{array}{l}\text { Malaspina et al. } \\
\text { 2011 [11] }\end{array}$ & PD-1, PD-L1 & $\begin{array}{l}\text { OSCC, } \\
\text { Actinic } \\
\text { Chelitis }\end{array}$ & N/A & $\begin{array}{l}\text { High PD-1 expression in CD4+ (43\%) and CD8+ }(68 \%) \\
\text { T cells may be used as a potential prognostic marker } \\
\text { in oral tumours or in pre-malignant lesions }\end{array}$ \\
\hline $\begin{array}{l}\text { Maruse et al. } 2018 \\
\text { [30] }\end{array}$ & PD-1, PD-L1 & OSCC & N/A & $\begin{array}{l}\text { Co-expression of PD-L1 and PD-1 is predictive of } \\
\text { a poor prognosis in OSCC patients }\end{array}$ \\
\hline $\begin{array}{l}\text { Moratin et al. } \\
2019[32]\end{array}$ & PD-L1 & OsCC & $\begin{array}{l}\text { AntiPD-1/PD-L1 therapy may be of therapeutic use in } \\
\text { early stage OSCC to prevent disease progression }\end{array}$ & $\begin{array}{l}\text { There was a trend toward worse overall survival for } \\
\text { patients with higher PD-L1 expression }\end{array}$ \\
\hline $\begin{array}{l}\text { Moreira et al. } \\
2010[33]\end{array}$ & CTLA4 & OSCC & N/A & $\begin{array}{c}\text { No association between CTLA-4 expression and } \\
\text { survival }\end{array}$ \\
\hline $\begin{array}{l}\text { Muller et al. } 2017 \\
\text { [34] }\end{array}$ & PD-L1 & OSCC & N/A & $\begin{array}{l}\text { PD-L1 expression is a suitable biomarker for poor } \\
\text { prognosis }\end{array}$ \\
\hline $\begin{array}{l}\text { Naruse et al. } 2019 \\
\text { [35] }\end{array}$ & PD-1, PD-L1 & OSCC & $\begin{array}{l}\text { Inhibition of PD-1/PD-L1 axis may improve outcomes } \\
\text { after non-adjuvant chemotherapy }\end{array}$ & $\begin{array}{c}\text { Patients with combined PD-1+/PD-L1+ expressions } \\
\text { had decreased 5-year disease-specific survival rate in } \\
\text { oral tongue SCC }\end{array}$ \\
\hline $\begin{array}{l}\text { Ngamphaiboon et } \\
\text { al. } 2019 \text { [36] }\end{array}$ & PD-L1 & OsCC & N/A & $\begin{array}{c}\text { PD-L1 expression above } 50 \% \text { indicated poor overall } \\
\text { survival }\end{array}$ \\
\hline $\begin{array}{c}\text { Okada et al. } 2018 \\
\text { [18] }\end{array}$ & PD-L1 & OSCC & N/A & $\begin{array}{l}\text { Low PD-L1 group had a better overall survival rate } \\
\text { than high PD-L1 group ( } 72.5 \% \text { vs } 16.7 \%)\end{array}$ \\
\hline $\begin{array}{l}\text { Ryu et al. } 2017 \\
\text { [38] }\end{array}$ & PD-1 & OSCC & N/A & High PD- $1+T$ cells indicate worse prognosis \\
\hline
\end{tabular}


Table 4. Cont

\begin{tabular}{|c|c|c|c|c|}
\hline Author/Year & Biomarker & $\begin{array}{l}\text { Tumour } \\
\text { Type }\end{array}$ & Predictive Value & Prognostic Value \\
\hline $\begin{array}{c}\text { Sablin et al. } 2016 \\
\text { [39] }\end{array}$ & PD-L1 & OscC & $\mathrm{N} / \mathrm{A}$ & $\begin{array}{l}\text { Overexpression of PD-L1 gene associated with poor } \\
\text { outcome }\end{array}$ \\
\hline $\begin{array}{c}\text { Seiwert et al. } 2016 \\
\text { [41] }\end{array}$ & PD-L1 & OscC & $\begin{array}{l}\text { PD-L1 expression by IHC was predictive of best } \\
\text { overall response and improved progression-free } \\
\text { survival }\end{array}$ & $\mathrm{N} / \mathrm{A}$ \\
\hline $\begin{array}{l}\text { Shayan et al. } 2017 \\
\text { [54] }\end{array}$ & PD-L1, CTLA-4 & OsCC & $\begin{array}{l}\text { Addition of a PD-1 inhibitor to cetuximab and } \\
\text { motolimod increases the antitumor response }\end{array}$ & N/A \\
\hline $\begin{array}{l}\text { Sridharan et al. } \\
\text { 2016 [59] }\end{array}$ & $\begin{array}{l}\text { PD-1, Tim3, } \\
\text { PD-L1 }\end{array}$ & OscC & N/A & $\begin{array}{l}\text { Higher baseline levels of soluble PD-L1 correlated } \\
\text { with nodal status }\end{array}$ \\
\hline $\begin{array}{l}\text { Straub et al. } 2016 \\
\text { [81] }\end{array}$ & PD-1, PD-L1 & OsCC & N/A & $\begin{array}{l}\text { PD-L1 positivity indicates increased risk of nodal } \\
\text { metastasis, recurrence and death }\end{array}$ \\
\hline $\begin{array}{l}\text { Troeltzsch et al. } \\
\quad 2017 \text { [44] }\end{array}$ & PD-L1 & OsCC & N/A & $\begin{array}{c}\text { PD-L1 expression is associated with increased } \\
\text { metastasis }\end{array}$ \\
\hline $\begin{array}{l}\text { Wang et al. } 2019 \\
\text { [45] }\end{array}$ & $\begin{array}{l}\text { PD-L1, TIM3, } \\
\text { CTLA4, Lag-3 }\end{array}$ & OsCC & N/A & $\begin{array}{l}\text { Aberrant LAG-3 and PD-L1 expression was } \\
\text { associated with worse survival }\end{array}$ \\
\hline $\begin{array}{l}\text { Weber et al. } 2018 \\
\text { [68] }\end{array}$ & PD-L1 & OscC & N/A & $\begin{array}{c}\text { Peripheral blood PD-L1 expression indicates } \\
\text { metastatic disease }\end{array}$ \\
\hline $\begin{array}{l}\text { Wong et al. } 2006 \\
\text { [69] }\end{array}$ & CTLA4 & OscC & N/A & $\begin{array}{l}\text { CTLA-4 A/A genotype polymorphism is associated } \\
\text { with poorer survival }\end{array}$ \\
\hline Wu et al. 2019 [60] & PD-1 & OsCC & $\begin{array}{c}\text { Blockage of PD-1 and TIGIT elicits better anti-tumour } \\
\text { effects }\end{array}$ & $\mathrm{N} / \mathrm{A}$ \\
\hline $\begin{array}{c}\text { Yagyuu et al. } 2017 \\
\text { [48] }\end{array}$ & PD-L1 & $\begin{array}{l}\text { Oral } \\
\text { Precancerous } \\
\text { Lesions }\end{array}$ & N/A & $\begin{array}{l}\text { Subepithelial PD-L1-positive cell count and epithelial } \\
\text { PD-L1 positivity were significantly associated with } \\
\text { malignant transformation }\end{array}$ \\
\hline $\begin{array}{c}\text { Yoo et al. } 2019 \\
\text { [50] }\end{array}$ & PD-L1 & OscC & N/A & $\begin{array}{l}\text { Loss of MHC class I expression is significantly } \\
\text { associated with a worse prognosis in PD-L1-positive } \\
\text { OCSCC (hazard ratio }=4.24 \text { ) }\end{array}$ \\
\hline
\end{tabular}


In terms of prognostic value, Malaspina et al. found that high PD-1 expression in CD4+ $(43 \%)$ and CD8+ $(68 \%) \mathrm{T}$ cells may be used as a marker of poor prognosis in OSCC and in actinic cheilitis [11]. Furthermore, Naruse et al. determined that combined expression of PD-1 and PD-L1 significantly decreased the 5-year survival of OSCC patients [35]. Maruse et al. examined the 5-year survival of OSCC patients and found that PD-L1 positivity was associated with approximately $20 \%$ lower survival than PD-L1 negativity, however found no significant difference in 5-year survival between PD-1-positive and negative groups [30]. Both PD-L1 and PD-1 expression is significantly associated with cervical lymph node metastasis, with odds ratios of 3.67 and 3.99, respectively [30], and higher baseline levels of soluble PD-L1 correlated with nodal status, with higher expression levels in patients with node-positive disease [59]. Okada et al. showed that the 5-year overall survival rates in low and high PD-L1 groups were $72.5 \%$ and $16.7 \%$, respectively [18], and Ngamphaiboon et al. showed that highly expressed PD-L1 ( $\geq 50 \%$ ) was an independent prognostic factor for poor overall survival in anti-PD-1/PD-L1 untreated OSCC patients [36], further supporting PD-L1 as a prognostic biomarker of OSCC. These results indicate that expression of PD-L1, and possibly PD-1, are useful predictive biomarkers of disease response to immunotherapy and are potentially useful prognostic biomarkers for poor prognosis and disease progression and metastasis.

In studies using IHC, PD-L1 exhibited membranous and cytoplasmic expression in OSCC [34,72], with minimal nuclear staining [35,40], and higher expression was observed in OSCC compared to oral leukoplakia [22]. Cytoplasmic PD-L1 expression was histologically found in areas with poorly differentiated cells showing nuclear atypia [19,75]. PD-1 IHC expression was limited to lymphocytes infiltrating or surrounding tumour nests [35] with higher expression in OSCC compared to actinic cheilitis [11], while CTLA-4 was expressed in TILs within the TME in contrast to Tregs [46,73,80]. IHC analysis showed that TIM-3 was expressed at a higher rate in CD4 and CD8 T cells compared with matched normal blood samples [79], and treatment of OSCC with nimotuzumab appeared to increase the expression of PD-L1, CTLA-4, TIM-3 and LAG-3 [45].

Malignant transformation of OPMD is a significant contributor to poor disease outcome. From the included studies, Yagyuu et al. [48] was the only article to examine the association of malignant transformation of OPMD and the expression of immune checkpoint molecules. This study demonstrated that in oral precancerous lesions, subepithelial PD-L1-positive cell count and epithelial PD-L1 positivity were significantly associated with malignant transformation, and therefore are indicators of a poor prognosis of OPMD. Despite this, more evidence is required to comprehensively understand the link between immune checkpoint biomarkers and malignant transformation of OPMD.

Similarly, only two of the included studies compared OPMD to OSCC lesions, therefore it is difficult to compare the significance of immune checkpoint molecule expression between these disease states. Chen et al. 2019 [22] assessed PD-L1 expression between OSCC and OLK and determined that expression was greater in OSCC than OLK, suggesting that relative abundance of PD-L1 may be an indicator of disease progression. Furthermore, Malaspina et al. [11] demonstrated that OSCC tumour samples showed higher expression of PD- 1 and higher numbers of CD4+ PD-1+ T cells when compared with tissue from actinic cheilitis patients, and in turn from healthy controls, further suggesting the possible capacity of expression to indicate disease severity and progression. Given that these studies were not longitudinal in nature, it is difficult to draw any meaningful conclusions in relation to malignant progression, hence further studies with stronger evidence are required to assess a possible relationship.

Therapeutic drug trials are still being conducted with the aim of delivering targeted therapies with less side effects. The role of immune checkpoint inhibitor chemotherapeutic treatment and PD-L1 expression was explored in OSCC [43,87]. Pembrolizumab (anti-PD-1) is FDA-approved for the management of patients with recurrent or metastatic OSCC $[41,88]$. It exhibits anti-tumour activity and an acceptable safety profile compared to cabazitaxel [16]. Falco et al. found that 22 out of 40 patients examined achieved clinical benefit from pembrolizumab-partial response seen in 10, stable disease 9, and complete response in 3 patients [87]. Nivolumab (anti-PD-1) was found to 
prolong survival rate compared to standard therapy with fewer toxic side effects [25]. The role of PD-1/PD-L1 immune checkpoint molecules are currently being investigated in relation to radiation therapy. PD-L1 indicate radio-sensitivity while survivin and c-Met implicates radio-resistance [26]. Moreover, fractionated chemoradiation leads to quantifiable effects and balance between suppressive and stimulatory mechanisms, which will be helpful when combined with immune checkpoint blockade [59]. Many genes are involved in tumorigenesis pathways, but of interest, six genes (PGF, PD-L1/CD274, CDK6, EGFR, MET, VEGFA) are overexpressed in HNSCC and associated with poorer outcome [39]. Furthermore, mPDCD1 (methylated PD-1 promotor) might potentially serve as a predictive biomarker for the response to immunotherapies targeting the PD-1/PD-L1 axis [66]. As noted by Feldman et al. in relation to HNSCC management, data supports the use of specific agents (PIK3CA, PD-1/PD-L1), combination strategies (PIK3CA plus EGFR) or agents approved for other solid tumours such as MGMT $\left(\mathrm{O}^{6}\right.$-methylguanine DNA methyltransferase) or HER2 (human epidermal growth factor receptor 2) [24]. PD-1 methylation may aid in identifying HNSCC patients who might benefit from targeted immunotherapy against the PD-1/PD-L1 pathway [66]. Combination therapy with docetaxel, platinum, and fluorouracil modifies PD-L1 expression by increasing PD-L1 positivity [28]. This has great implications when trying to craft a therapeutic strategy.

Current literature on the use of immune checkpoint inhibitors in OSCC focuses on their efficacy in improving overall survival and progression-free survival. A recent systematic review by Ghanizada et al. examined the effect of immunotherapy on HNSCC, summarizing that checkpoint inhibition exhibits an anti-tumour effect [90]. Building on this study, our systematic review examines the predictive and prognostic value of immune checkpoint biomarkers, and also compares OSCC with OPMD. Similarly, another recent systematic review by Yang et al. examined the prognostic role of PD-L1 in HNSCC, and our analysis builds on this by examining other immune checkpoint biomarkers, as well as their predictive values [91]. Both of these articles broadly examine HNSCC, therefore our study fills a crucial gap in the specific examination of OSCC and the comparison to OPMD precursor lesions.

A limitation of our systematic review is the reported low quality of the included articles. Many of these articles have a high level of bias, therefore it is difficult to compare results between studies. Furthermore, the range of article types means that no single quality assessment tool was sufficient to grade them all, therefore it was necessary to utilize both QUADAS-2 and QUIPS to determine the quality of included articles. The low-quality of included articles highlights that future research should focus on improving study design and accounting for bias, as well as improving the adequacy and suitability of control tissue for comparison to both OPMD and OSCC. Comparison of OPMD and progression to OSCC in longitudinal patient cohorts is also required.

\section{Conclusions}

The studies included in this systematic review examined the expression of immune checkpoint molecules in human OSCC and OPMD. There is a significant gap in the literature pertaining to the comparative expression of these biomarkers to normal tissue and there is a need to standardize detection methods and the classification of positive expression across different tumour types and subsites within the oral cavity, in order to make the data less ambiguous. Despite the equivocal nature of current evidence, there is support for the prognostic and predictive values of immune checkpoint molecules, especially PD-L1, and many studies provide support for the effective use of immune checkpoint inhibitors in the management of OSCC. Limited data is available for OPMD, therefore this should be the focus of future research.

Supplementary Materials: The following are available online at http://www.mdpi.com/2072-6694/12/7/1937/s1, Table S1: Summary of inclusion criteria data from the included articles; Table S2: Summarized results of included articles.

Author Contributions: O.K. developed the concept of the study, undertook systematic review of articles, undertook quality assessments, drafted the manuscript and checked the final manuscript. B.V.S. undertook systematic review of articles, undertook quality assessments, and drafted manuscript. C.S.F. devised the study, checked the findings, 
drafted the manuscript and checked the final manuscript. All authors have read and agreed to the published version of the manuscript.

Funding: This research received no external funding.

Conflicts of Interest: The authors declare no potential conflict of interest.

\section{References}

1. Miller, K.D.; Siegel, R.L.; Lin, C.C.; Mariotto, A.B.; Kramer, J.L.; Rowland, J.H.; Stein, K.D.; Alteri, R.; Jemal, A. Cancer treatment and survivorship statistics. CA Cancer J. Clin. 2016, 66, 271-289. [CrossRef]

2. Guo, L.; Zhao, Y.; Yang, S.; Zhang, H.; Chen, F. An integrated analysis of miRNA, lncRNA, and mRNA expression profiles. Biomed. Res. Int. 2014, 2014, 345605. [CrossRef]

3. Almokadem, S. Progress in Immunotherapy of Head and Neck Squamous Cell Carcinoma. Curr. Mol. Pharmacol. 2016, 9, 226-230. [CrossRef]

4. Sharma, P.; Allison, J.P. The future of immune checkpoint therapy. Science 2015, 348, 56-61. [CrossRef] [PubMed]

5. Disis, M.L. Mechanism of Action of Immunotherapy. Semin. Oncol. 2014, 41, S3-S13. [CrossRef] [PubMed]

6. Amarnath, S.; Costanzo, C.M.; Mariotti, J.; Ullman, J.L.; Telford, W.G.; Kapoor, V.; Riley, J.L.; Levine, B.L.; June, C.H.; Fong, T.; et al. Regulatory T cells and human myeloid dendritic cells promote tolerance via programmed death ligand-1. PLoS Biol. 2010, 8, e1000302. [CrossRef] [PubMed]

7. Ribas, A. Tumor immunotherapy directed at PD-1. N. Engl. J. Med. 2012, 366, 2517-2519. [CrossRef] [PubMed]

8. Zandberg, D.P.; Strome, S.E. The role of the PD-L1: PD-1 pathway in squamous cell carcinoma of the head and neck. Oral Oncol. 2014, 50, 627-632. [CrossRef]

9. Shi, L.; Chen, S.; Yang, L.; Li, Y. The role of PD-1 and PD-L1 in T-cell immune suppression in patients with hematological malignancies. J. Hematol. Oncol. 2013, 6, 74. [CrossRef] [PubMed]

10. Scognamiglio, T.; Chen, Y.T. Beyond the Percentages of PD-L1-Positive Tumor Cells: Induced Versus Constitutive PD-L1 Expression in Primary and Metastatic Head and Neck Squamous Cell Carcinoma. Head Neck Pathol. 2017, 12, 221-229. [CrossRef]

11. Malaspina, T.S.; Gasparoto, T.H.; Costa, M.R.; de Melo, E.F., Jr.; Ikoma, M.R.; Damante, J.H.; Cavassani, K.A.; Garlet, G.P.; da Silva, J.S.; Campanelli, A.P. Enhanced programmed death 1 (PD-1) and PD-1 ligand (PD-L1) expression in patients with actinic cheilitis and oral squamous cell carcinoma. Cancer Immunol. Immunother. 2011, 60, 965-974. [CrossRef]

12. Moher, D.; Liberati, A.; Tetzlaff, J.; Altman, D.G. Preferred reporting items for systematic reviews and meta-analyses: The PRISMA statement. Ann. Intern. Med. 2009, 151, 264-269. [CrossRef]

13. Whiting, P.F.; Rutjes, A.W.; Westwood, M.E.; Mallett, S.; Deeks, J.J.; Reitsma, J.B.; Leeflang, M.M.; Sterne, J.A.; Bossuyt, P.M. QUADAS-2: A revised tool for the quality assessment of diagnostic accuracy studies. Ann. Intern. Med. 2011, 155, 529-536. [CrossRef] [PubMed]

14. Hayden, J.A.; van der Windt, D.A.; Cartwright, J.L.; Cote, P.; Bombardier, C. Assessing bias in studies of prognostic factors. Ann. Intern. Med. 2013, 158, 280-286. [CrossRef] [PubMed]

15. Balermpas, P.; Rodel, F.; Krause, M.; Linge, A.; Lohaus, F.; Baumann, M.; Tinhofer, I.; Budach, V.; Sak, A.; Stuschke, M.; et al. The PD-1/PD-L1 axis and human papilloma virus in patients with head and neck cancer after adjuvant chemoradiotherapy: A multicentre study of the German Cancer Consortium Radiation Oncology Group (DKTK-ROG). Int. J. Cancer 2017, 141, 594-603. [CrossRef] [PubMed]

16. Bauml, J.; Seiwert, T.Y.; Pfister, D.G.; Worden, F.; Liu, S.V.; Gilbert, J.; Saba, N.F.; Weiss, J.; Wirth, L.; Sukari, A.; et al. Pembrolizumab for Platinum- and Cetuximab-Refractory Head and Neck Cancer: Results From a Single-Arm, Phase II Study. J. Clin. Oncol. 2017, 35, 1542-1549. [CrossRef] [PubMed]

17. Groeger, S.; Howaldt, H.P.; Raifer, H.; Gattenloehner, S.; Chakraborty, T.; Meyle, J. Oral Squamous Carcinoma Cells Express B7-H1 and B7-DC Receptors in Vivo. Pathol. Oncol. Res. 2017, 23, 99-110. [CrossRef]

18. Okada, S.; Itoh, K.; Ishihara, S.; Shimada, J.; Kato, D.; Tsunezuka, H.; Miyata, N.; Hirano, S.; Teramukai, S.; Inoue, M. Significance of PD-L1 expression in pulmonary metastases from head and neck squamous cell carcinoma. Surg. Oncol. 2018, 27, 259-265. [CrossRef]

19. Cai, Y.; Wang, F.; Liu, Q.; Li, Z.; Li, D.; Sun, Z. A novel humanized anti-PD-1 monoclonal antibody potentiates therapy in oral squamous cell carcinoma. Investig. New Drugs 2019, 37, 799-809. [CrossRef] 
20. Chen, S.-C.; Chang, P.M.-H.; Wang, H.-J.; Tai, S.-K.; Chu, P.-Y.; Yang, M.-H. PD-L1 expression is associated with p16(INK4A) expression in non-oropharyngeal head and neck squamous cell carcinoma. Oncol. Lett. 2018, 15, 2259-2265.

21. Chen, T.C.; Wu, C.T.; Wang, C.P.; Hsu, W.L.; Yang, T.L.; Lou, P.J.; Ko, J.Y.; Chang, Y.L. Associations among pretreatment tumor necrosis and the expression of HIF-1alpha and PD-L1 in advanced oral squamous cell carcinoma and the prognostic impact thereof. Oral Oncol. 2015, 51, 1004-1010. [CrossRef] [PubMed]

22. Chen, X.J.; Tan, Y.Q.; Zhang, N.; He, M.J.; Zhou, G. Expression of programmed cell death-ligand 1 in oral squamous cell carcinoma and oral leukoplakia is associated with disease progress and CD8+ tumor-infiltrating lymphocytes. Pathol. Res. Pract. 2019, 215, 152418. [CrossRef]

23. Cho, Y.A.; Yoon, H.J.; Lee, J.I.; Hong, S.P.; Hong, S.D. Relationship between the expressions of PD-L1 and tumor-infiltrating lymphocytes in oral squamous cell carcinoma. Oral Oncol. 2011, 47, 1148-1153. [CrossRef] [PubMed]

24. Feldman, R.; Gatalica, Z.; Knezetic, J.; Reddy, S.; Nathan, C.A.; Javadi, N.; Teknos, T. Molecular profiling of head and neck squamous cell carcinoma. Head Neck 2016, 38 (Suppl. 1), E1625-E1638. [CrossRef]

25. Ferris, R.L.; Blumenschein, G., Jr.; Fayette, J.; Guigay, J.; Colevas, A.D.; Licitra, L.; Harrington, K.; Kasper, S.; Vokes, E.E.; Even, C.; et al. Nivolumab for Recurrent Squamous-Cell Carcinoma of the Head and Neck. N. Engl. J. Med. 2016, 375, 1856-1867. [CrossRef] [PubMed]

26. Fiedler, M.; Weber, F.; Hautmann, M.G.; Haubner, F.; Reichert, T.E.; Klingelhoffer, C.; Schreml, S.; Meier, J.K.; Hartmann, A.; Ettl, T. Biological predictors of radiosensitivity in head and neck squamous cell carcinoma. Clin. Oral Investig. 2017, 22, 189-200. [CrossRef]

27. Foy, J.P.; Bertolus, C.; Michallet, M.C.; Deneuve, S.; Incitti, R.; Bendriss-Vermare, N.; Albaret, M.A.; Ortiz-Cuaran, S.; Thomas, E.; Colombe, A.; et al. The immune microenvironment of HPV-negative oral squamous cell carcinoma from never-smokers and never-drinkers patients suggests higher clinical benefit of IDO1 and PD1/PD-L1 blockade. Ann. Oncol. 2017, 28, 1934-1941. [CrossRef]

28. Leduc, C.; Adam, J.; Louvet, E.; Sourisseau, T.; Dorvault, N.; Bernard, M.; Maingot, E.; Faivre, L.; Cassin-Kuo, M.-S.; Boissier, E.; et al. TPF induction chemotherapy increases PD-L1 expression in tumour cells and immune cells in head and neck squamous cell carcinoma. ESMO Open 2018, 3, e000257. [CrossRef]

29. Lin, Y.M.; Sung, W.W.; Hsieh, M.J.; Tsai, S.C.; Lai, H.W.; Yang, S.M.; Shen, K.H.; Chen, M.K.; Lee, H.; Yeh, K.T.; et al. High PD-L1 Expression Correlates with Metastasis and Poor Prognosis in Oral Squamous Cell Carcinoma. PLoS ONE 2015, 10, e0142656. [CrossRef]

30. Maruse, Y.; Kawano, S.; Jinno, T.; Matsubara, R.; Goto, Y.; Kaneko, N.; Sakamoto, T.; Hashiguchi, Y.; Moriyama, M.; Toyoshima, T.; et al. Significant association of increased PD-L1 and PD-1 expression with nodal metastasis and a poor prognosis in oral squamous cell carcinoma. Int. J. Oral Maxillofac. Surg. 2018, 47, 836-845. [CrossRef]

31. Mattox, A.; Lee, J.; Westra, W.H.; Pierce, R.H.; Ghossein, R.; Faquin, W.C.; Diefenbach, T.J.; Morris, L.G.; Lin, D.T.; Wirth, L.J.; et al. PD-1 expression in head and neck squamous cell carcinomas derives primarily from functionally anergic CD4+ TILs in the presence of PD-L1+ TAMs. Cancer Res. 2017, 77, 6365-6374. [CrossRef] [PubMed]

32. Moratin, J.; Metzger, K.; Safaltin, A.; Herpel, E.; Hoffmann, J.; Freier, K.; Hess, J.; Horn, D. Upregulation of PD-L1 and PD-L2 in neck node metastases of head and neck squamous cell carcinoma. Head Neck 2019, 41, 2484-2491. [CrossRef] [PubMed]

33. Moreira, G.; Fulgencio, L.B.; Ef, D.E.M.; Leles, C.R.; Batista, A.C.; Ta, D.A.S. T regulatory cell markers in oral squamous cell carcinoma: Relationship with survival and tumor aggressiveness. Oncol. Lett. 2010, 1, 127-132. [CrossRef]

34. Muller, T.; Braun, M.; Dietrich, D.; Aktekin, S.; Hoft, S.; Kristiansen, G.; Goke, F.; Schrock, A.; Bragelmann, J.; Held, S.A.E.; et al. PD-L1: A novel prognostic biomarker in head and neck squamous cell carcinoma. Oncotarget 2017, 8, 52889-52900. [CrossRef] [PubMed]

35. Naruse, T.; Yanamoto, S.; Okuyama, K.; Ohmori, K.; Tsuchihashi, H.; Furukawa, K.; Yamada, S.I.; Umeda, M. Immunohistochemical Study of PD-1/PD-L1 Axis Expression in Oral Tongue Squamous Cell Carcinomas: Effect of Neoadjuvant Chemotherapy on Local Recurrence. Pathol. Oncol. Res. 2019, 26, 735-742. [CrossRef] [PubMed] 
36. Ngamphaiboon, N.; Chureemas, T.; Siripoon, T.; Arsa, L.; Trachu, N.; Jiarpinitnun, C.; Pattaranutaporn, P.; Sirachainan, E.; Larbcharoensub, N. Characteristics and impact of programmed death-ligand 1 expression, CD8+ tumor-infiltrating lymphocytes, and p16 status in head and neck squamous cell carcinoma. Med. Oncol. 2019, 36, 21. [CrossRef]

37. Rasmussen, J.H.; Lelkaitis, G.; Hakansson, K.; Vogelius, I.R.; Johannesen, H.H.; Fischer, B.M.; Bentzen, S.M.; Specht, L.; Kristensen, C.A.; von Buchwald, C.; et al. Intratumor heterogeneity of PD-L1 expression in head and neck squamous cell carcinoma. Br. J. Cancer 2019, 120, 1003-1006. [CrossRef]

38. Ryu, H.J.; Kim, E.K.; Heo, S.J.; Cho, B.C.; Kim, H.R.; Yoon, S.O. Architectural patterns of p16 immunohistochemical expression associated with cancer immunity and prognosis of head and neck squamous cell carcinoma. Acta Pathol. Microbiol. Et Immunol. Scand. 2017, 125, 974-984. [CrossRef]

39. Sablin, M.P.; Dubot, C.; Klijanienko, J.; Vacher, S.; Ouafi, L.; Chemlali, W.; Caly, M.; Sastre-Garau, X.; Lappartient, E.; Mariani, O.; et al. Identification of new candidate therapeutic target genes in head and neck squamous cell carcinomas. Oncotarget 2016, 7, 47418-47430. [CrossRef]

40. Satgunaseelan, L.; Gupta, R.; Madore, J.; Chia, N.; Lum, T.; Palme, C.E.; Boyer, M.; Scolyer, R.A.; Clark, J.R. Programmed cell death-ligand 1 expression in oral squamous cell carcinoma is associated with an inflammatory phenotype. Pathology 2016, 48, 574-580. [CrossRef]

41. Seiwert, T.Y.; Burtness, B.; Mehra, R.; Weiss, J.; Berger, R.; Eder, J.P.; Heath, K.; McClanahan, T.; Lunceford, J.; Gause, C.; et al. Safety and clinical activity of pembrolizumab for treatment of recurrent or metastatic squamous cell carcinoma of the head and neck (KEYNOTE-012): An open-label, multicentre, phase $1 \mathrm{~b}$ trial. Lancet Oncol. 2016, 17, 956-965. [CrossRef]

42. Takahashi, H.; Sakakura, K.; Arisaka, Y.; Tokue, A.; Kaira, K.; Tada, H.; Higuchi, T.; Okamoto, A.; Tsushima, Y.; Chikamatsu, K. Clinical and Biological Significance of PD-L1 Expression Within the Tumor Microenvironment of Oral Squamous Cell Carcinoma. Anticancer Res. 2019, 39, 3039-3046. [CrossRef] [PubMed]

43. Takakura, H.; Domae, S.; Ono, T.; Sasaki, A. The Immunological Impact of Chemotherapy on the Tumor Microenvironment of Oral Squamous Cell Carcinoma. Acta Med. Okayama 2017, 71, 219-226. [PubMed]

44. Troeltzsch, M.; Woodlock, T.; Pianka, A.; Otto, S.; Troeltzsch, M.; Ehrenfeld, M.; Knosel, T. Is There Evidence for the Presence and Relevance of the PD-1/PD-L1 Pathway in Oral Squamous Cell Carcinoma? Hints From an Immunohistochemical Study. J. Oral Maxillofac. Surg. 2017, 75, 969-977. [CrossRef]

45. Wang, H.; Mao, L.; Zhang, T.; Zhang, L.; Wu, Y.; Guo, W.; Hu, J.; Ju, H.; Ren, G. Altered expression of TIM-3, LAG-3, IDO, PD-L1, and CTLA-4 during nimotuzumab therapy correlates with responses and prognosis of oral squamous cell carcinoma patients. J. Oral Pathol. Med. 2019, 48, 669-676. [CrossRef]

46. Wu, L.; Deng, W.W.; Huang, C.F.; Bu, L.L.; Yu, G.T.; Mao, L.; Zhang, W.F.; Liu, B.; Sun, Z.J. Expression of VISTA correlated with immunosuppression and synergized with CD8 to predict survival in human oral squamous cell carcinoma. Cancer Immunol. Immunother. 2017, 66, 627-636. [CrossRef] [PubMed]

47. Xu, B.; Jungbluth, A.A.; Frosina, D.; Alzumaili, B.; Aleynick, N.; Slodkowska, E.; Higgins, K.; Ho, A.; Morris, L.; Ghossein, R.; et al. The immune microenvironment and expression of PD-L1, PD-1, PRAME and MHC I in salivary duct carcinoma. Histopathology 2019, 75, 672-682. [CrossRef]

48. Yagyuu, T.; Hatakeyama, K.; Imada, M.; Kurihara, M.; Matsusue, Y.; Yamamoto, K.; Obayashi, C.; Kirita, T. Programmed death ligand 1 (PD-L1) expression and tumor microenvironment: Implications for patients with oral precancerous lesions. Oral Oncol. 2017, 68, 36-43. [CrossRef]

49. Yang, L.L.; Mao, L.; Wu, H.; Chen, L.; Deng, W.W.; Xiao, Y.; Li, H.; Zhang, L.; Sun, Z.J. pDC depletion induced by CD317 blockade drives the antitumor immune response in head and neck squamous cell carcinoma. Oral Oncol. 2019, 96, 131-139. [CrossRef]

50. Yoo, S.H.; Keam, B.; Ock, C.Y.; Kim, S.; Han, B.; Kim, J.W.; Lee, K.W.; Jeon, Y.K.; Jung, K.C.; Chung, E.J.; et al. Prognostic value of the association between MHC class I downregulation and PD-L1 upregulation in head and neck squamous cell carcinoma patients. Sci. Rep. 2019, 9, 7680. [CrossRef]

51. Youngnak-Piboonratanakit, P.; Tsushima, F.; Otsuki, N.; Igarashi, H.; Machida, U.; Iwai, H.; Takahashi, Y.; Omura, K.; Yokozeki, H.; Azuma, M. The expression of B7-H1 on keratinocytes in chronic inflammatory mucocutaneous disease and its regulatory role. Immunol. Lett. 2004, 94, 215-222. [CrossRef] [PubMed]

52. Gasparoto, T.H.; de Souza Malaspina, T.S.; Benevides, L.; de Melo, E.J., Jr.; Costa, M.R.; Damante, J.H.; Ikoma, M.R.; Garlet, G.P.; Cavassani, K.A.; da Silva, J.S.; et al. Patients with oral squamous cell carcinoma are characterized by increased frequency of suppressive regulatory $\mathrm{T}$ cells in the blood and tumor microenvironment. Cancer Immunol. Immunother. 2010, 59, 819-828. [CrossRef] [PubMed] 
53. Hanna, G.J.; Liu, H.; Jones, R.E.; Bacay, A.F.; Lizotte, P.H.; Ivanova, E.V.; Bittinger, M.A.; Cavanaugh, M.E.; Rode, A.J.; Schoenfeld, J.D.; et al. Defining an inflamed tumor immunophenotype in recurrent, metastatic squamous cell carcinoma of the head and neck. Oral Oncol. 2017, 67, 61-69. [CrossRef]

54. Shayan, G.; Kansy, B.A.; Gibson, S.P.; Srivastava, R.M.; Bryan, J.K.; Bauman, J.E.; Ohr, J.; Kim, S.; Duvvuri, U.; Clump, D.A.; et al. Phase Ib Study of Immune Biomarker Modulation with Neoadjuvant Cetuximab and TLR8 Stimulation in Head and Neck Cancer to Overcome Suppressive Myeloid Signals. Clin. Cancer Res. 2018, 24, 62-72. [CrossRef] [PubMed]

55. Strauss, L.; Bergmann, C.; Whiteside, T.L. Functional and phenotypic characteristics of CD4+CD25highFoxp3+ Treg clones obtained from peripheral blood of patients with cancer. Int. J. Cancer 2007, 121, 2473-2483. [CrossRef]

56. Jie, H.B.; Gildener-Leapman, N.; Li, J.; Srivastava, R.M.; Gibson, S.P.; Whiteside, T.L.; Ferris, R.L. Intratumoral regulatory T cells upregulate immunosuppressive molecules in head and neck cancer patients. Br. J. Cancer 2013, 109, 2629-2635. [CrossRef] [PubMed]

57. Pekiner, F.N.; Demirel, G.Y.; Borahan, M.O.; Ozbayrak, S. Evaluation of cytotoxic T-cell activation, chemokine receptors, and adhesion molecules in blood and serum in patients with oral lichen planus. J. Oral Pathol. Med. 2012, 41, 484-489. [CrossRef] [PubMed]

58. Poropatich, K.; Fontanarosa, J.; Swaminathan, S.; Dittmann, D.; Chen, S.; Samant, S.; Zhang, B. Comprehensive T-cell immunophenotyping and next-generation sequencing of human papillomavirus (HPV)-positive and HPV-negative head and neck squamous cell carcinomas. J. Pathol. 2017, 243, 354-365. [CrossRef]

59. Sridharan, V.; Margalit, D.N.; Lynch, S.A.; Severgnini, M.; Zhou, J.; Chau, N.G.; Rabinowits, G.; Lorch, J.H.; Hammerman, P.S.; Hodi, F.S.; et al. Definitive chemoradiation alters the immunologic landscape and immune checkpoints in head and neck cancer. Br. J. Cancer 2016, 115, 252-260. [CrossRef]

60. Wu, L.; Mao, L.; Liu, J.F.; Chen, L.; Yu, G.T.; Yang, L.L.; Wu, H.; Bu, L.L.; Kulkarni, A.B.; Zhang, W.F.; et al. Blockade of TIGIT/CD155 Signaling Reverses T-cell Exhaustion and Enhances Antitumor Capability in Head and Neck Squamous Cell Carcinoma. Cancer Immunol. Res. 2019, 7, 1700-1713. [CrossRef]

61. Zhou, G.; Zhang, J.; Ren, X.W.; Hu, J.Y.; Du, G.F.; Xu, X.Y. Increased B7-H1 expression on peripheral blood T cells in oral lichen planus correlated with disease severity. J. Clin. Immunol. 2012, 32, 794-801. [CrossRef] [PubMed]

62. Bharti, V.; Mohanti, B.K.; Das, S.N. Functional genetic variants of CTLA-4 and risk of tobacco-related oral carcinoma in high-risk North Indian population. Hum. Immunol. 2013, 74, 348-352. [CrossRef] [PubMed]

63. Kammerer, P.W.; Toyoshima, T.; Schoder, F.; Kammerer, P.; Kuhr, K.; Brieger, J.; Al-Nawas, B. Association of T-cell regulatory gene polymorphisms with oral squamous cell carcinoma. Oral Oncol. 2010, 46, 543-548. [CrossRef] [PubMed]

64. Singh, R.; De Sarkar, N.; Sarkar, S.; Roy, R.; Chattopadhyay, E.; Ray, A.; Biswas, N.K.; Maitra, A.; Roy, B. Analysis of the whole transcriptome from gingivo-buccal squamous cell carcinoma reveals deregulated immune landscape and suggests targets for immunotherapy. PLoS ONE 2017, 12, e0183606. [CrossRef] [PubMed]

65. Bhosale, P.G.; Cristea, S.; Ambatipudi, S.; Desai, R.S.; Kumar, R.; Patil, A.; Kane, S.; Borges, A.M.; Schaffer, A.A.; Beerenwinkel, N.; et al. Chromosomal Alterations and Gene Expression Changes Associated with the Progression of Leukoplakia to Advanced Gingivobuccal Cancer. Transl. Oncol. 2017, 10, 396-409. [CrossRef]

66. Goltz, D.; Gevensleben, H.; Dietrich, J.; Schroeck, F.; de Vos, L.; Droege, F.; Kristiansen, G.; Schroeck, A.; Landsberg, J.; Bootz, F.; et al. PDCD1 (PD-1) promoter methylation predicts outcome in head and neck squamous cell carcinoma patients. Oncotarget 2017, 8, 41011-41020. [CrossRef] [PubMed]

67. Strati, A.; Koutsodontis, G.; Papaxoinis, G.; Angelidis, I.; Zavridou, M.; Economopoulou, P.; Kotsantis, I.; Avgeris, M.; Mazel, M.; Perisanidis, C.; et al. Prognostic significance of PD-L1 expression on circulating tumor cells in patients with head and neck squamous cell carcinoma. Ann. Oncol. 2017, 28, 1923-1933. [CrossRef]

68. Weber, M.; Wehrhan, F.; Baran, C.; Agaimy, A.; Büttner-Herold, M.; Preidl, R.; Neukam, F.W.; Ries, J. PD-L1 expression in tumor tissue and peripheral blood of patients with oral squamous cell carcinoma. Oncotarget 2017, 8, 112584-112597. [CrossRef]

69. Wong, Y.K.; Chang, K.W.; Cheng, C.Y.; Liu, C.J. Association of CTLA-4 gene polymorphism with oral squamous cell carcinoma. J. Oral Pathol. Med. 2006, 35, 51-54. [CrossRef] 
70. Ahn, H.; Yang, J.M.; Kim, H.; Chung, J.H.; Ahn, S.H.; Jeong, W.J.; Paik, J.H. Clinicopathologic implications of the miR-197/PD-L1 axis in oral squamous cell carcinoma. Oncotarget 2017, 8, 66178-66194. [CrossRef]

71. Du, G.H.; Qin, X.P.; Li, Q.; Zhou, Y.M.; Shen, X.M.; Tang, G.Y. The high expression level of programmed death-1 ligand 2 in oral lichen planus and the possible costimulatory effect on human T cells. J. Oral Pathol. Med. 2011, 40, 525-532. [CrossRef] [PubMed]

72. Hanna, G.J.; Woo, S.B.; Li, Y.Y.; Barletta, J.A.; Hammerman, P.S.; Lorch, J.H. Tumor PD-L1 expression is associated with improved survival and lower recurrence risk in young women with oral cavity squamous cell carcinoma. Int. J. Oral Maxillofac. Surg. 2017, 47, 568-577. [CrossRef] [PubMed]

73. Katou, F.; Ohtani, H.; Watanabe, Y.; Nakayama, T.; Yoshie, O.; Hashimoto, K. Differing phenotypes between intraepithelial and stromal lymphocytes in early-stage tongue cancer. Cancer Res. 2007, 67, 11195-11201. [CrossRef]

74. Lecerf, C.; Kamal, M.; Vacher, S.; Chemlali, W.; Schnitzler, A.; Morel, C.; Dubot, C.; Jeannot, E.; Meseure, D.; Klijanienko, J.; et al. Immune gene expression in head and neck squamous cell carcinoma patients. Eur. J. Cancer 2019, 121, 210-223. [CrossRef]

75. Oliveira-Costa, J.P.; de Carvalho, A.F.; da Silveira da, G.G.; Amaya, P.; Wu, Y.; Park, K.J.; Gigliola, M.P.; Lustberg, M.; Buim, M.E.; Ferreira, E.N.; et al. Gene expression patterns through oral squamous cell carcinoma development: PD-L1 expression in primary tumor and circulating tumor cells. Oncotarget 2015, 6, 20902-20920. [CrossRef] [PubMed]

76. Wirsing, A.M.; Ervik, I.K.; Seppola, M.; Uhlin-Hansen, L.; Steigen, S.E.; Hadler-Olsen, E. Presence of high-endothelial venules correlates with a favorable immune microenvironment in oral squamous cell carcinoma. Mod. Pathol. 2018, 31, 910-922. [CrossRef] [PubMed]

77. Linedale, R.; Schmidt, C.; King, B.T.; Ganko, A.G.; Simpson, F.; Panizza, B.J.; Leggatt, G.R. Elevated frequencies of CD8 T cells expressing PD-1, CTLA-4 and Tim-3 within tumour from perineural squamous cell carcinoma patients. PLoS ONE 2017, 12, e0175755. [CrossRef]

78. Malm, I.J.; Bruno, T.C.; Fu, J.; Zeng, Q.; Taube, J.M.; Westra, W.; Pardoll, D.; Drake, C.G.; Kim, Y.J. Expression profile and in vitro blockade of programmed death-1 in human papillomavirus-negative head and neck squamous cell carcinoma. Head Neck 2015, 37, 1088-1095. [CrossRef]

79. Quan, H.; Fang, L.; Pan, H.; Deng, Z.; Gao, S.; Liu, O.; Wang, Y.; Hu, Y.; Fang, X.; Yao, Z.; et al. An adaptive immune response driven by mature, antigen-experienced $\mathrm{T}$ and $\mathrm{B}$ cells within the microenvironment of oral squamous cell carcinoma. Int. J. Cancer 2016, 138, 2952-2962. [CrossRef]

80. Lechner, A.; Schlosser, H.; Rothschild, S.I.; Thelen, M.; Reuter, S.; Zentis, P.; Shimabukuro-Vornhagen, A.; Theurich, S.; Wennhold, K.; Garcia-Marquez, M.; et al. Characterization of tumor-associated T-lymphocyte subsets and immune checkpoint molecules in head and neck squamous cell carcinoma. Oncotarget 2017, 8, 44418-44433. [CrossRef]

81. Straub, M.; Drecoll, E.; Pfarr, N.; Weichert, W.; Langer, R.; Hapfelmeier, A.; Gotz, C.; Wolff, K.D.; Kolk, A.; Specht, K. CD274/PD-L1 gene amplification and PD-L1 protein expression are common events in squamous cell carcinoma of the oral cavity. Oncotarget 2016, 7, 12024-12034. [CrossRef] [PubMed]

82. Aggarwal, S.; Sharma, S.C.; Das, S.N. Dynamics of regulatory T cells (Tregs ) in patients with oral squamous cell carcinoma. J. Surg. Oncol. 2017, 116, 1103-1113. [CrossRef] [PubMed]

83. Dong, J.; Cheng, L.; Zhao, M.; Pan, X.; Feng, Z.; Wang, D. Tim-3-expressing macrophages are functionally suppressed and expanded in oral squamous cell carcinoma due to virus-induced Gal-9 expression. Tumour Biol. 2017, 39, 1010428317701651. [CrossRef] [PubMed]

84. Ghapanchi, J.; Ghaderi, H.; Haghshenas, M.R.; Jamshidi, S.; Rezazadeh, F.; Azad, A.; Farzin, M.; Derafshi, R.; Kalantari, A.H. Observational Molecular Case-Control Study of Genetic Polymorphisms 1 in Programmed Cell Death Protein-1 in Patients with Oral Lichen Planus. Asian Pac. J. Cancer Prev. 2019, 20, 421-424. [CrossRef]

85. Fayette, J.; Guigay, J.; Le Tourneau, C.; Degardin, M.; Peyrade, F.; Neidhardt, E.M.; Sablin, M.P.; Even, C.; Orlandini, F.; Juzyna, B.; et al. Cabazitaxel in recurrent/metastatic squamous cell carcinoma of the head and neck: Phase II UNICANCER trial ORL03. Oncotarget 2017, 8, 51830-51839. [CrossRef]

86. Saada-Bouzid, E.; Defaucheux, C.; Karabajakian, A.; Coloma, V.P.; Servois, V.; Paoletti, X.; Even, C.; Fayette, J.; Guigay, J.; Loirat, D.; et al. Hyperprogression during anti-PD-1/PD-L1 therapy in patients with recurrent and/or metastatic head and neck squamous cell carcinoma. Ann. Oncol. 2017, 28, 1605-1611. [CrossRef] 
87. Falco, A.; Angel, M.; Perez, J.F.; Cayol, F.; Pucella, I.; Gomez Abuin, G.; Florez, J.; Adelchanow, E.; Palazzo, J.; Palazzo, F.; et al. Immunotherapy in Advanced Head and Neck Squamous Cell Carcinoma: A Retrospective Evaluation in Latin America. Biomed. J. Sci. Tech. Res. 2019, 17, 12708-12712. [CrossRef]

88. Larkins, E.; Blumenthal, G.M.; Yuan, W.; He, K.; Sridhara, R.; Subramaniam, S.; Zhao, H.; Liu, C.; Yu, J.; Goldberg, K.B.; et al. FDA Approval Summary: Pembrolizumab for the Treatment of Recurrent or Metastatic Head and Neck Squamous Cell Carcinoma with Disease Progression on or After Platinum-Containing Chemotherapy. Oncolologist 2017, 22, 873-878. [CrossRef]

89. Fathi, F.; Faghih, Z.; Khademi, B.; Kayedi, T.; Erfani, N.; Gahderi, A. PD-1 Haplotype Combinations and Susceptibility of Patients to Squamous Cell Carcinomas of Head and Neck. Immunol. Investig. 2019, 48, 1-10. [CrossRef]

90. Ghanizada, M.; Jakobsen, K.K.; Grønhøj, C.; von Buchwald, C. The effects of checkpoint inhibition on head and neck squamous cell carcinoma: A systematic review. Oral Oncol. 2019, 90, 67-73. [CrossRef]

91. Yang, W.F.; Wong, M.C.M.; Thomson, P.J.; Li, K.Y.; Su, Y.X. The prognostic role of PD-L1 expression for survival in head and neck squamous cell carcinoma: A systematic review and meta-analysis. Oral Oncol. 2018, 86, 81-90. [CrossRef] [PubMed]

(C) 2020 by the authors. Licensee MDPI, Basel, Switzerland. This article is an open access article distributed under the terms and conditions of the Creative Commons Attribution (CC BY) license (http://creativecommons.org/licenses/by/4.0/). 